\title{
OPTIMALISASI PENGELOLAAN DAN PELAYANAN TRANSPORTASI UMUM (Studi pada "Suroboyo Bus" di Surabaya)
}

\author{
Arini Sulistyowati, Imam Muazansyah \\ arinisulistyowati@uwp.ac.id \\ Universitas Wijaya Putra, Surabaya \\ alyacarpet@gmail.com \\ Universitas Kalimantan Utara
}

\begin{abstract}
ABSTRAK
Transportasi merupakan hal yang penting dalam kehidupan sehari-hari, sehingga sarana transportasi yang memadai sangat dibutuhkan. Akan tetapi, di Surabaya transportasi yang lebih didominasi oleh kendaraan pribadi menjadi dampak dari kemacetan, sehingga perlu adanya sistem transportasi umum yang dapat mengangkut massal penumpang dengan dilengkapi teknologi canggih yang menjamin keamanan penumpang. Pemerintah kota Surabaya menyediakan Suroboyo Bus sebagai transportasi umum yang dapat dimanfaatkan oleh masyarakat hanya dengan menggunakan sampah botol plastik sebagai pembayaran, namun hal tersebut belum cukup efektif mengingat masih banyaknya permasalahan-permasalahan yang ditimbulkan, sehingga terlihat kurang dimanfaatkan oleh masyarakat secara optimal. Perencanaan dan pemodelan transportasi adalah media yang paling efektif dan efisien yang dapat menggabungkan semua faktor tersebut dan keluarannya dapat digunakan untuk memecahkan permasalahan transportasi baik pada masa sekarang maupun pada masa yang akan datang.

Kata kunci: Transportasi Umum, Suroboyo Bus
\end{abstract}

\section{PENDAHULUAN}

Transportasi memegang peranan penting dalam usaha mencapai tujuan pengembangan ekonomi, kehidupan masyarakat dalam memenuhi kebutuhan pergerakan manusia dari tempat asal ke tempat tujuan supaya dapat dimanfaatkan di tempat yang bersangkutan, seperti pergerakan dari rumah menuju tempat sekolah, menuju tempat kerja, dan lain sebagainya. Kebutuhan akan angkutan penumpang tergantung fungsi bagi kegunaan seseorang (personal place utility). Semakin tingginya mobilitas masyarakat menyebabkan kebutuhan akan sarana transportasi juga semakin meningkat. Saat ini, transportasi umum darat telah menjadi angkutan yang sangat diminati karena kemudahan dari segi pelayanan. Disisi lain, transportasi umum darat juga menjadi alternatif kemacetan yang terjadi khususnya di Surabaya, mengingat Surabaya adalah kota terbesar kedua di Pulau Jawa setelah Jakarta. Kemacetan ini timbul karena semakin banyaknya kendaraan pribadi khususnya mobil pribadi.

Permasalahan transportasi yang sering ditemui di Indonesia adalah kurangnya fasilitas pelayanan transportasi, semakin bertambah jumlah kendaraan mengakibatkan kemacetan lalu lintas. Tidak hanya itu, kemacetan juga menghabiskan waktu yang terbuang. Transportasi umum yang terdapat di Indonesia tidak dilengkapi dengan fasilitas yang memadai. Kondisi fasilitas transportasi yang disediakan membuat masyarakat merasa kurang nyaman dengan 
layanan yang ditawarkan oleh transportasi umum tersebut. Kondisi tersebut membuat masyarakat lebih memilih menggunakan kendaraan pribadi dibandingkan menggunakan transportasi umum. Tidak hanya fasilitas minim yang dimiliki oleh transportasi umum, pemberhentian transportasi umum tersebut tidak diatur dengan menggunakan jadwal. Masyarakat yang tidak mengetahui waktu tepat dimana transportasi umum tersebut berhenti di halte membuat masyarakat tidak memiliki kepastian akan kendaraan umum yang akan mereka gunakan.

Menurut Walikota Surabaya, Tri Rismaharini volume kendaraan di Surabaya terus meningkat dari tahun ke tahun, sehingga transportasi massal merupakan alternatif yang dinilai tepat mengurangi kepadatan kendaraan. Karena perbandingan kendaraan pribadi dengan transportasi massal saat ini $75 \%$ dan 25\%. Kalau sampai tembus angka $90 \%$ maka jalanan di Surabaya akan berhenti. Idealnya memang 50 banding 50 (Kompasiana, 2018).

Tabel 1.1. Banyaknya Kendaraan Bermotor menurut Jenisnya

Tahun 2009- 2015

\begin{tabular}{|c|c|c|c|c|c|c|c|}
\hline Jenis Kendaraan & 2009 & 2010 & 2011 & 2012 & 2013 & 2014 & 2015 \\
\hline $\begin{array}{l}\text { Sedan Dan } \\
\text { Sejenisnya }\end{array}$ & 51.610 & 50.555 & 48.258 & 47.459 & 50.164 & 53.024 & 56.046 \\
\hline Jeep Dan Sejenisnya & 29.022 & 29.601 & 28.312 & 29.635 & 31.324 & 33.110 & 34.997 \\
\hline $\begin{array}{l}\text { STWAGON Dan } \\
\text { Sejenisnya }\end{array}$ & 183.645 & $` 198.960$ & $` 199.360$ & 217.686 & 230.094 & 243.209 & 257.072 \\
\hline Bus Dan sejenisnya & 2.064 & 2.279 & 2.304 & 2.486 & 2.628 & 2.777 & 2.936 \\
\hline Truk Dan Sejenis nya & 86.987 & -89.530 & 92.238 & 100.809 & 106.555 & 112.629 & 119.049 \\
\hline $\begin{array}{l}\text { Speda motor Dan } \\
\text { Sejenisnya }\end{array}$ & 1.129 .870 & 1.213 .457 & 1.274 .660 & $` 1.402 .190$ & 1.482 .115 & 1.566 .595 & 1.655 .891 \\
\hline $\begin{array}{l}\text { Alat berat Dan } \\
\text { sejenisnya }\end{array}$ & 73 & 71 & 80 & 150 & 159 & 168 & 177 \\
\hline Jumlah & 1.483 .271 & 1.584 .453 & 1.645 .212 & 1800,415 & 1.903 .039 & 2.011 .512 & 2.126 .168 \\
\hline
\end{tabular}

Sumber : Polantas Kota Besar Surabaya,

https://surabayakota.bps.go.id/statictable/2018/01/11/572/banyaknya-kendaraan-bermotor-menurut-jenisnya2009-----2015.html diakses pada tanggal 7 Agustus 2018.

Pemerintah selalu berupaya menekan angka kemacetan yang terjadi di Surabaya salah satunya dengan menyediakan sarana transportasi umum yang dapat mempermudah masyarakat dalam memenuhi kebutuhan pergerakannya. Pemanfaatan transportasi umum masyarakat di Indonesia masih rendah dikarenakan rendahnya sosialisasi maupun kesadaran masyarakat didalamnya. Berbeda dengan di beberapa Negara maju seperti halnya di Korea Selatan yang berhasil mengurangi tingkat kemacetan dengan membatasi jumlah kendaraan pribadi. Saat ini, transportasi di Seoul didominasi kendaraan umum, yaitu bus umum sebanyak 28 persen, subway sebanyak 37 persen, taksi 7 persen, sepeda dan alat transportasi lain sebanyak 4,4 persen serta kendaraan pribadi yang hanya berjumlah 23,5 persen (Sunaryo, 2015). Demikian halnya, di Singapura yang menganjurkan warga memanfaatkan transportasi umum seperti bus dan kereta (MRT dan LRT) dengan membuat kebijakan yang sengaja menaikkan biaya memiliki mobil guna pembatasan jumlah mobil pribadi (BBC News, 2017).

Pemerintah kota Surabaya dengan mengacu sistem transportasi di luar negeri tersebut berupaya menurunkan tingkat kemacetan dengan meluncurkan Suroboyo Bus yang merupakan armada transportasi umum milik Pemerintah Kota Surabaya. Dinas Perhubungan Kota Surabaya menilai keberadaan "Suroboyo Bus" bisa menurunkan angka kecelakaan lalu lintas, 
dikarenakan moda transportasi ini terintegrasi dengan sistem pengaturan lalu lintas jalan. Lampu lalu lintas secara otomatis akan berubah menjadi hijau jika bus ini melintas. Pusat kontrolnya ada di Terminal Bratang dan Joyoboyo. Suroboyo Bus juga dilengkapi dengan 12 kamera CCTV pada bagian dalam dan 3 kamera CCTV yang disematkan pada bagian luar. Keberadaan kamera-kamera ini untuk memberikan rasa aman bagi penumpang. Kemudian pintu bus juga dilengkapi sensor sehingga jika ada penumpang yang menghalangi, pintu tidak akan tertutup dan bus tidak akan berjalan. Selain itu, bus dengan lebar 2,4 meter dan panjang 12 meter juga dilengkapi tombol darurat jika terjadi kebakaran atau kecelakaan maka pengemudi bus dapat menekan tombol dan alarm akan berbunyi, kemudian pintu bus terbuka secara otomatis (Puspita, 2018).

Selain mengurangi kemacetan di Surabaya, Suroboyo Bus juga diluncurkan dengan tujuan untuk mengurangi sampah yang ada di Surabaya, karena penumpang tidak perlu membayar dengan uang, melainkan dengan menukarkan sampah botol plastik bekas air mineral berupa 5 botol bekas air mineral $600 \mathrm{ml}$ atau 10 gelas bekas air mineral $250 \mathrm{ml}$ dan atau 3 botol bekas air mineral 1,5 liter. Sedangkan bagi penumpang yang tidak ingin menenteng sampah kalau mau pergi naik bis ini, dapat menukarkan di bank sampah, drop box halte dan drop box terminal Purabaya yang telah bekerjasama dengan DKRTH. Sampah tersebut bisa di ganti dengan kartu setor sampah untuk ditukar dengan tiket (Kompasiana, 2018). Selain itu, Suroboyo Bus nyaman dan memiliki berbagai macam manfaat karena ramah untuk penyandang difabel, lansia dan ibu hamil. Pemkot Surabaya telah menyediakan tombol khusus dekat pintu masuk jika dipencet, asisten pengemudi akan membantu penyandang difabel untuk masuk ke dalam bus (Puspita, 2018).

Suroboyo Bus ini diharapkan dapat dimanfaatkan sebaik mungkin oleh masyarakat dalam menjalankan aktivitasnya sehari-hari agar dapat mengurangi penggunaan kendaraan pribadi sehingga kemacetan dapat diantisipasi. Akan tetapi pengoperasian Suroboyo Bus masih kurang maksimal. Hal ini terlihat dari masih sepinya penumpang yang memanfaatkan Suroboyo Bus dalam memenuhi kebutuhan sebagai transportasi umum. Pada awal Suroboyo Bus resmi beroperasi terdapat enam dari delapan armada yang dioperasikan, namun jumlah penumpang masih jauh dari harapan. Sepanjang rute Rajawali - Terminal Purabaya tidak ada penumpang yang naik. Kemudian rute Terminal Purabaya - Rajawali hingga kembali ke Terminal Purabaya total penumpang hanya 16 orang (Jawa Pos, 2018).

Sepinya penumpang pada Suroboyo Bus tersebut diindikasikan oleh kurangnya sosialisasi yang dilakukan kepada masyarakat, sehingga menyebabkan banyaknya masyarakat yang tidak tahu tentang keberadaan transportasi tersebut. Selain itu, kurangnya sosialisasi menjadikan masyarakat tidak memahami mekanisme pembayaran dengan menggunakan sampah plastik, sehingga membuat masyarakat enggan menggunakan alat transportasi tersebut (Jawa Pos, 2018). Disamping itu, adanya ketidakpuasan masyarakat akan kinerja yang tidak sesuai dengan yang dinjanjikan juga menjadi faktor rendahnya tingkat pemanfaatan Suroboyo Bus oleh masyarakat sebagai transportasi umum, seperti durasi tunggu bus yang terlalu lama, layanan rute yang terbatas, masih belum berfungsinya fasilitas antitraffic sehingga masih terjebak macet serta aplikasi Gobis yang belum dapat digunakan dengan maksimal (Jawa Pos, 2018). 


\section{KAJIAN TEORI \\ Transportasi}

Salim (2012) mendefinisikan transportasi sebagai kegiatan pemindahan barang (muatan) dan penumpang dari suatu tempat ketempat lain, sedangkan Adisasmita (2011) menyatakan bahwa transportasi adalah kegiatan memindahkan atau mengangkut muatan (barang dan manusia) dari suatu tempat ketempat lain, dari suatu tempat asal (origin) ketempat tujuan (destination). Menurut Miro (2012), transportasi merupakan salah satu kunci perkembangan suatu Daerah atau Kota. Transportasi diartikan sebagai pemindahan barang dan manusia dari tempat asal ketempat tujuan, proses pengangkutan merupakan gerakan dari tempat asal, dari mana kegiatan angkutan dimulai, ketempat tujuan, kemana kegiatan pengangkutan diakhiri. Transportasi bisa diartikan sebagai usaha memindahkan, menggerakkan, mengangkut, atau mengalihkan suatu objek dari suatu tempat ke tempat lain dimana ditempat lain, objek tersebut lebih bermanfaat atau dapat berguna untuk tujuan-tujuan tertentu.

Menurut Salim (2012), dalam transportasi ada dua unsur yang terpenting yaitu pemindahan/pergerakan (movement) dan secara fisik mengubah tempat dari barang dan penumpang ke tempat lain. Transportasi menurut Nasution (2008) didefinisikan sebagai pemindahan barang dan manusia dari tempat asal ke tempat tujuan. Proses pengangkutan merupakan gerakan dari tempat asal, dari mana kegiatan angkutan dimulai, ke tempat tujuan, ke mana kegiatan pengangkutan. Kamaluddin (2003) menjelaskan bahwa transportasi merupakan kegiatan pemindahan barang (muatan) dan penumpang dari suatu tempat ke tempat lain. Unsur-unsur transportasi terdiri dari:

1. Manusia yang membutuhkan

2. Barang yang dibutuhkan

3. Kendaraan sebagai alat/sarana

4. Jalan dan terminal sebagai prasarana transportasi

5. Organisasi (pengelola transportasi).

Masing-masing moda transportasi menurut Setijowarno dan Frazila (2001), memiliki ciri-ciri yang berlainan, yakni dalam hal:

1. Kecepatan, menunjukan berapa lama waktu yang dibutuhkan untuk bergerak antara dua lokasi.

2. Tersedianya pelayanan (availability of service), menyangkut kemampuan untuk menyelenggarakan hubungan antara dua lokasi.

3. Pengoperasiaan yang diandalkan (dependability of operation), menunjukan perbedaanperbedaan yang terjadi antara kenyataan dan jadwal yang ditentukan.

4. Kemampuan (capability), merupakan kemampuan untuk dapat menangani segala bentuk dan keperluan akan pengangkutan.

5. Frekuensi adalah banyaknya gerakan atau hubungan yang dijadwalkan.

\section{Transportasi Publik}

Transportasi umum merupakan suatu kegiatan memindahkan manusia atau barang dari suatu tempat ketempat yang lain menggunakan sarana angkutan umum dengan membayarkan sejumlah biaya tertentu. Dalam hal perangkutan umum melibatkan beberapa pihak, yaitu operator sebagai penyedia pelayanan angkutan umum, masyarakat sebagai konsumen atau pengguna layanan jasa angkutan umum, dan pemerintah sebagai regulator atau pengatur dan penengah antara operator angkutan dan masyarakat (Warpani, 2002).

Tujuan utama keberadaan transportasi umum penumpang adalah menyelenggarakan pelayanan angkutan yang baik dan layak bagi masyarakat. Ukuran pelayanan yang baik adalah pelayanan yang aman, cepat, murah dan nyaman. Selain itu, keberadaan angkutan umum penumpang juga membuka lapangan kerja. Ditinjau dengan kacamata perlalu-lintasan, 
keberadaan angkutan umum penumpang mengandung arti pengurangan volume lalu lintas kendaraan pribadi, hal ini dimungkinkan karena angkutan umum penumpang bersifat angkutan massal sehingga biaya angkut dapat dibebankan kepada lebih banyak orang atau penumpang. Banyaknya penumpang menyebabkan biaya penumpang dapat ditekan serendah mungkin (Warpani, 2002).

\section{Moda Transportasi Darat}

Menurut Warpani (2002) Moda transportasi darat terdiri dari seluruh bentuk alat transportasi yang beroperasi di darat. Moda transportasi darat sering dianggap identik dengan moda transportasi jalan raya. Moda transportasi darat terdiri dari berbagai varian jenis alat transportasi dengan ciri khusus. Kemudian Miro (2012) menjelaskan bahwa transportasi darat dapat di klasifikasikan menjadi:

1. Geografis Fisik, terdiri dari moda transportasi jalan rel, moda transportasi perairan daratan, moda transportasi khusus dari pipa dan kabel serta moda transportasi jalan raya.

2. Geografis Administratif, terbagi atas transportasi dalam kota, transportasi desa, transportasi antar-kota dalam provinsi (AKDP), transportasi antar-kota antara-provinsi (AKAP) dan transportasi lintas batas antar-negara (internasional)

Surya (2006) menyatakan bahwa kebijakan penyediaan moda angkutan darat beberapa kota metropolitan di Indonesia cenderung menggunakan pendekatan populis. Pendekatan ini mengacu kepada kemampuan moda angkutan darat untuk mengangkut sebanyak mungkin penumpang yang bermukim di pinggiran dan pusat kota.

\section{Manajemen Transportasi}

Manajemen transportasi adalah sebagai usaha dalam mencapai tujuan yang telah ditentukan dengan penghasilan jasa angkutan oleh perusahaan angkutan sedemikian rupa, sehingga dengan tarif yang berlaku dapat memenuhi kepentingan umum. Menurut Nasution (2008:30) pada umumnya manajemen transportasi menghadapi tiga tugas utama, yaitu:

1. Menyusun rencana dan progam untuk mencapai tujuan dan misi organisasi secara keseluruhan.

2. Meningkatkan produktivitas dan kinerja perusahaan.

3. Dampak sosial dan tanggung jawab sosial dalam pengoperasikan angkutan kota.

Menurut Griffin (2004:226) manajemen strategi atau strategis (strategic management) adalah cara untuk menanggapi peluang dan tantangan bisnis. Manajemen strategis merupakan proses manajemen yang komprehensif dan berkelanjutan yang ditujukan untuk memformulasikan dan mengimplementasikan strategi yang efektif.

\section{Public Private Partnership (PPP)}

Public Private Partnership (PPP) atau KPS dapat diterjemahkan sebagai perjanjian kontrak antara swasta dan pemerintah, yang keduanya bergabung bersama dalam sebuah kerjasama untuk menggunakan keahlian dan kemampuan masing-masing untuk meningkatkan pelayanan kepada publik di mana kerjasama tersebut dibentuk untuk menyediakan kualitas pelayanan terbaik dengan biaya yang optimal untuk publik (America's National Council on Public Private Partnership) (Kurniawan, dkk, 2009).

PPP merupakan alat untuk meningkatkan efisiensi dan meningkatkan kualitas produkproduk dan pelayanan publik. Tujuan dilakukannya Private Partnership atau PPP, antara lain 
adalah untuk meningkatkan efektivitas dan efisiensi dalam pelaksanaannya, meningkatkan kualitas produk-produk dan pelayanan publik, dan adanya pembagian modal, risiko, dan kompetensi atau keahlian sumber daya manusia secara bersama-sama (Susantono dan Berawi, 2012).

Di lain pihak konsep PPP tidak hanya dapat dipandang dari sisi public dan private sector saja, akan tetapi merupakan triangle synergy antara government, business, dan communities. Seperti penjelasan yang terdapat pada laporan United Nations Development Program (2004), United Nations Economic Commission for Europe (2008), dan Asian Development Bank (2008), para pihak PPP yang dapat dikategorikan menjadi 3 unsur, yaitu:

1. Negara, berfungsi menciptakan lingkungan politik dan hukum yang kondusif.

2. Swasta, mendorong terciptanya lapangan pekerjaan dan peningkatan pendapatan masyarakat.

3. Masyarakat, mewadahi interaksi sosial politik, memobilisasi kelompok dalam masyarakat untuk berpartisipasi dalam aktivitas ekonomi sosial dan politik.

\section{METODE PENELITIAN}

Metode penelitian menggunakan studi literatur yaitu peneliti menelaah secara tekun akan kepustakaan yang diperlukan dalam penelitian (Nazir, 2014). Penelitian ini menggunakan pendekatan penelitian kualitatif sebagai penelitian eksploratif yang tidak terstruktur. Studi literatur, selain dari mencari sumber data sekunder yang akan mendukung penelitian, juga diperlukan untuk mengetahui sampai ke mana ilmu yang berhubungan dengan penelitian telah berkembang, sampai ke mana terdapat kesimpulan dan degeneralisasi yang telah pernah dibuat, sehingga situasi yang diperlukan dapat diperoleh (Nazir, 2014).

Penelitian kualitatif ini menggunakan sumber data sekunder. Data sekunder, yaitu data yang tidak langsung memberikan data kepada peneliti (Sugiyono, 2014) atau data yang telah dikumpulkan oleh lembaga pengumpulan data dan dipublikasikan kepada masyarakat pengguna data. Data sekunder dalam penelitian ini diperoleh dari referensi yang diperoleh melalui studi kepustakaan, seperti buku-buku referensi, jurnal, artikel, dan sumber lainnya yang relevan dengan penelitian.

Penelitian ini menggunakan penelitian kualitatif dengan metode studi literatur, sehingga pengumpulan data dalam penelitian ini selain dari buku referensi digunakan juga sumbersumber berikut ini (Nazir, 2014):

1. Buku teks yaitu buku ilmiah yang ditulis rapi yang diterbitkan dengan interval yang tidak tentu.

2. Jurnal, yaitu majalah ilmiah yang berisi tulisan ilmiah atau hasil-hasil seminar.

3. Periodical, yaitu majalah ilmiah yang diterbitkan secara berkala oleh lembaga-lembaga baik pemerintah atau swasta yang berisi hasil penelitian.

Dalam penelitian ini tinjauan terhadap literatur lokal dan internasional terpilih. Data dalam laporan ini dibandingkan, diringkas, dan diinterpretasikan untuk mendapatkan hasil yang berguna terkait dengan transportasi Suroboyo Bus.

\section{HASIL PENELITIAN DAN PEMBAHASAN}

\section{Perbedaan Transportasi Umum di Indonesia dan Luar Negeri}

Transportasi umum khususnya bus di Indonesia belum banyak dimanfaatkan oleh masyarakat. Hal ini berbeda dengan transportasi umum di beberapa negara lainnya seperti di Seoul Korea Selatan yang sejak tahun 2004 melakukan berbagai reformasi di bidang angkutan umum dengan mulai membangun manajemen angkutan umum dengan nama Transport Operation and Information Service (Topis). Dalam satu ruangan yang dinamakan Seoul Control Center (SCC), yang terletak di Seoul City, Kompleks Balai Kota, manajemen lalu lintas termasuk transportasi umum di Kota Seoul bisa terpantau melalui ratusan CCTV (Closed 
Circuit Television) yang terpasang di sudut kota. Saat ini, mayoritas kendaraan yang dimanfaatkan oleh sebagian besar penduduk setempat adalah transportasi umum yaitu bus umum sebanyak 28 persen, subway sebanyak 37 persen, taksi 7 persen, sepeda dan alat transportasi lain sebanyak 4,4 persen serta kendaraan pribadi yang hanya berjumlah 23,5 persen (Sunaryo, 2015). Pemerintah Seoul menyediakan sekitar 7.500 unit bus untuk moda transportasi di jalan raya. Ribuan bus tersebut dibedakan menjadi 3 warna. Warna biru adalah bus connecting subsurb, hijau bus untuk veeder line yang menyambungkan ke jalur arteri. Sedangkan bus warna kuning rutenya dibatasi untuk wilayah bisnis dan pusat perbelanjaan saja (Sunaryo, 2015).

Pada negara lainnya seperti Singapura, telah memiliki sistem transportasi yang meningkat pesat meskipun sebelumnya tidak jauh berbeda dengan sistem transportasi di Indonesia. Saat ini Singapura memiliki transportasi massal 4.500 bus dengan 300 rute perjalanan yang secara umum tiap harinya melayani 3,6 juta orang penumpang (Khafifah, 2015). Sistem transportasi yang baik didukung dengan adanya kebijakan negara Singapura tersebut memiliki strategi perencanaan jangka panjang dan tata guna lahan untuk transportasi terintegrasi. Kebijakan perencanaan kota Singapura dilakukan melalui perancangan konsep atau concept plan, yang disusun dan direvisi secara berkala (Berita Trans, 2015). Terlebih pemerintah telah membatasi jumlah mobil pribadi untuk mengatasi kemacetan dengan berinvestasi besar-besaran di jaringan transportasi umum negara tersebut khususnya untuk subsidi kontrak bus sebesar S\$4 miliar (Rp 40 triliun) (BBC News, 2017).

Berbeda dengan sistem transportasi di dua negara tersebut, Indonesia masih jauh dari harapan, seperti adanya Suroboyo Bus sebagai transportasi umum yang menyediakan berbagai kecanggihan dalam sarana transportasi umum namun belum sepenuhnya dapat dimanfaatkan dengan baik oleh sebagian besar masyarakat. Sebagian besar masyarakat di Indonesia termasuk di Surabaya lebih banyak menggunakan kendaraan pribadi daripada transportasi publik termasuk Suroboyo Bus.

\section{Kesepakatan Bersama Pemerintah dan Swasta}

Dalam mendukung Suroboyo Bus sebagai transportasi umum, diperlukan adanya Kebijakan yang didasari oleh kesepakatan bersama Pemerintah Kota Surabaya dengan Pihak Swasta dengan perencanaan, pengaorganisasian, aktualisasi serta control yang tepat Dalam pengoptimalan pengelolaan dan pelayanan transportasi umum pada Suroboyo Bus, akan dilakukan penerapan yang Optimal. Tujuan planning adalah mengidentifikasi seberapa jauh kebutuhan pengguna transportasi umum khususnya bus dan seberapa banyak pengguna potensial telah terpenuhi dan untuk menutup kesenjangan antara apa yang diberikan dengan apa yang dibutuhkan. Dalam hal ini terdapat dua elemen yakni mengevaluasi seluruh layanan yang tersedia; membuat keputusan mengenai jenis layanan apa saja yang dibutuhkan untuk memenuhi permintaan serta memenuhi tujuan kebijakan. Dalam perencanaan atau planning, data mengenai status dan kinerja sistem transportasi harus dipantau secara berkesinambungan, karena perencanaan harus dilakukan secara terus menerus. Berikut ini data yang mencakup indikator kinerja kuantitatif serta indikator yang mengukur sejauh mana permintaan, dalam hal kuantitas dan kualitas layanan, telah tercapai.

1. Indikator Kinerja

Sumber daya yang digunakan dalam penyelenggaraan transportasi umum bus harus digunakan semaksimal mungkin sehingga dapat lebih produktif dan efisien. Oleh karena itu, evaluasi kinerja operasional layanan bus dan standar layanan yang dijanjikan kepada pengguna (Standar Pelayanan Minimum) semakin dibutuhkan. Indikator kinerja yang 
ditentukan dapat memaparkan kelemahan dari pelayanan sehingga dapat diketahui perbaikan-perbaikan yang perlu untuk dilakukan dan menjadi sarana untuk mengevaluasi perbaikan dan perubahan. Indikator kinerja utama operasional berikut ini sangat dianjurkan (beberapa parameter diambil dari World Bank Technical Paper No 68 berjudul Meningkatkan Standar Layanan Bus dan Menurunkan Biaya) dalam Meakin (2011):

a. Volume penumpang

Indikator yang paling mendasar dari produktivitas adalah jumlah penumpang terangkut dalam kaitannya dengan kapasitas sistem. Hal ini diukur oleh rata-rata jumlah penumpang per bus operasi per hari. Suatu perusahaan bus yang sehat, dikelola dengan baik dan dengan permintaan yang tinggi sepanjang hari biasanya mencapai hingga 1.000 penumpang per bus per hari untuk bus tunggal dengan kapasitas maksimal 80. Dalam hal ini, planning dilakukan dengan mengukur jumlah rata-rata penumpang dalam sehari, penumpang per perjalanan yang ditempuh bus (penumpang/bus-km), serta jumlah perjalanan pulang-pergi yang ditempuh oleh setiap kendaraan per hari, sehingga dapat diketahui sejauh mana produktivitas Suroboyo Bus dapat efisien.

b. Pemanfaatan armada

Proporsi dari armada bus yang dioperasikan tiap harinya menunjukkan efektivitas pengadaan bus, perawatan, dan ketersediaan staf. Suatu perusahaan bus yang dijalankan dengan baik akan mencapai utilisasi armada sebesar 80-85 persen. Dengan mengacu pada kondisi awal menunjukkan bahwa jumlah armada Suroboyo Bus hanya 8 armada dan yang aktif beroperasi hanya 6 armada, sedangkan 2 armada lainnya digunakan sebagai cadangan ketika terjadi kerusakan. Dalam hal ini, planning dilakukan dengan mengukur kesesuaian jumlah armada bus dengan utilisasi agar diperoleh pemanfaatan armada yang efektif dan efisien.

c. Panjang tempuh kendaraan

Indikator lain dari produktivitas armada bus adalah jarak total yang ditempuh oleh bus dalam pelayanan, biasanya dinyatakan dalam kilometer rata-rata per bus per hari operasi. Suatu layanan bus yang cukup baik mencapai sekitar 210-260 buskilometer per bus per hari. Panjang trayek dan jumlah perjalanan pulang pergi per kendaraan per hari juga wajib dipantau. Oleh karena itu, planning dapat dilakukan dengan mengukur Panjang tempuh Suroboyo Bus dalam satu hari yang efektif dan efisien, karena trayek yang Panjang lebih rentan terhadap gangguan tundaan akibat kemacetan lalu lintas. Penjadwalan juga terkendala oleh hal ini.

d. Kerusakan dalam pelayanan

Armada bus yang cukup terawat baik tidak akan mengalami gangguan lebih dari 8-10 persen setiap hari dari total bus yang beroperasi. Operator dengan armada modern, terawat dengan baik dapat mencapai tingkat kehandalan yang sangat tinggi. Dengan mengacu pada kondisi lapangan setelah dioperasikannya Suroboyo Bus menemui kerusakan pada 2 armada bus yang tidak bias berfungsi karena adanya AC bocor (Surya, 2018). Dengan demikian planning dapat dilakukan dengan memastikan kondisi bus yang optimal dan jauh dari kemungkinan kerusakan yang dapat terjadi.

e. Konsumsi bahan bakar

Konsumsi bahan bakar tergantung pada ukuran dan beban kendaraan, bahan bakar dan jenis mesin dan alinyemen jalan serta kondisi lalu lintas pada trayek. Pemeliharaan dan perilaku pengemudi juga memiliki pengaruh yang cukup besar. 
Konsumsi bahan bakar dari suatu sistem yang berjalan baik adalah sekitar 20-25 liter per 100 kilometer untuk minibus.

f. Rasio pegawai

Angka rata-rata pegawai operasional, administrasi dan staf pemeliharaan per bus merupakan indikator efisiensi yang penting pada tingkat perusahaan. Angka yang dianggap cukup efisien adalah empat pegawai per bus. Perhitungan jumlah pegawai juga harus menggambarkan keperluan tenaga konduktor, jumlah shift per hari, bisa dua atau tiga, dan pekerjaan yang pihak ketiga (outsourcing) seperti perawatan dan pembersihan armada.

g. Kecelakaan

Tingkat kecelakaan memberikan indikasi standar perilaku pengemudi dan pemeliharaan. Pada dasarnya, peluncuran Suroboyo Bus bertujuan untuk meminimalkan tingkat kecelakaan, karena moda transportasi ini terintegrasi dengan sistem pengaturan lalu lintas jalan, yang mana lampu lalu lintas secara otomatis akan berubah menjadi hijau jika Suroboyo Bus melintas. Selain itu, pintu bus juga dilengkapi sensor sehingga jika ada penumpang yang menghalangi, pintu tidak akan tertutup dan bus tidak akan berjalan. Suroboyo Bus juga dilengkapi dengan tombol darurat jika terjadi kebakaran atau kecelakaan, yang mana pengemudi bus dapat menekan tombol dan alarm akan berbunyi, kemudian pintu bus terbuka secara otomatis. Akan tetapi, dengan mengacu pada kondisi temuan awal menunjukkan tidak berfungsinya fasilitas antitraffic sehingga masih terjebak macet (Jawa Pos, 2018). Pembuat kebijakan dan otoritas jalan raya telah berusaha untuk mempromosikan keselamatan dengan menetapkan batas kecepatan, menetapkan sinyal lalu lintas, menegakkan undang-undang lalu lintas dan menanggapi insiden lalu lintas. Teknologi dapat diimplementasikan dengan biaya sederhana untuk meningkatkan efektivitas tindakan tersebut. Oleh karena itu, perbaikan sistem antitraffic menjadi bagian planning yang penting agar kinerja Suroboyo Bus semakin optimal, karena menggunakan teknologi yang memungkinkan sinyal lalu lintas untuk merespons arus lalu lintas real-time dengan mengoptimalkan durasi sinyal lalu lintas dapat diterapkan lebih luas untuk meningkatkan keamanan dan mengurangi waktu perjalanan.

2. Indikator Kualitas Layanan

Hasil riset yang dilakukan diseluruh dunia sebagian besar pengguna transportasi umum mengutamakan keterandalan sebagai kualitas layanan yang penting dan paling utama dari jasa transportasi umum, kemudian juga frekuensi layaanan serta kecepatan perjalanan. Meskipun tidak ada standar bakuan yang jelas dalam mengukur kualitas layanan transportasi umum bus, namun terdapat beberapa atribut yang dapat diukur antara lain adalah:

a. Waktu tunggu

Waktu tunggu penumpang merupakan faktor utama dalam keseluruhan kualitas layanan. Di negara berkembang waktu tunggu rata-rata harus dalam wilayah 5-10 menit, dengan maksimal 10-20 menit. Waktu tunggu paling rendah berlaku untuk perjalanan yang cukup singkat dengan frekuensi layanan tinggi dan waktu tunggu yang tinggi akan berlaku untuk perjalanan panjang dan frekuensi layanan rendah. Akan tetapi dari hasil pemantauan Jawa Pos di lapangan menunjukkan masih lamanya waktu tunggu bus sekitar 30-40 menit yang berdampak akan beralihnya penumpang ke transportasi lain apabila masa tunggu Suroboyo Bus terlalu lama 
(Jawa Pos, 2018). Mengganti jasa paratransit yang terorganisir longgar dengan layanan yang terkoordinasi, bahkan tanpa menambah kendaraan, cenderung membuat frekuensi layanan lebih teratur dan mengurangi waktu tunggu rata-rata, serta menghilangkan waktu tunggu yang sangat panjang yang kadang-kadang terjadi dalam pelayanan paratransit. Dalam hal ini, planning dapat dilakukan dengan mengevaluasi dan memantau beberapa hal berikut ini:

1) Frekuensi kendaraan (headways) sepanjang hari untuk memperkirakan waktu menunggu rata-rata;

2) Volume beban kendaraan dan permintaan penumpang di sepanjang rute untuk mengidentifikasi situasi kelebihan muatan yang berakibat pada peningkatan waktu tunggu.

Dengan adanya perencanaan yang tepat diharapkan dapat meningkatkan produktivitas Suroboyo Bus sebagai transportasi umum.

b. Jarak berjalan kaki dengan rute bus

Jarak yang ditempuh penumpang dengan berjalan kaki ke dan dari halte bus adalah indikasi dari keterjangkauan jaringan layanan bus. Dalam jaringan yang cukup baik, penumpang dapat naik bus dalam radius 300 - 500 meter dari rumah mereka atau tempat kerja. Jarak lebih dari 500 meter dapat diterima untuk pemukiman berkepadatan rendah, tetapi jarak berjalan maksimum tidak boleh melebihi satu kilometer. Akan tetapi, pada kenyataannya, rute Suroboyo Bus masih sangat terbatas, sehingga banyak penumpang yang mengeluhkan keterjangkauan akses dan berharap kedepannya ada Suroboyo Bus yang melayani rute yang dekat kantorkantor, sekolah-sekolah dan tempat-tempat umum lainnya. Hal ini yang perlu menjadi perhatian dalam planning Suroboyo Bus kedepannya agar dapat lebih optimal dalam pemanfaatannya.

c. Waktu perjalanan

Penumpang tidak bisa diharapkan rela menghabiskan lebih dari dua sampai tiga jam setiap hari untuk bepergian ke dan dari tempat kerja (pintu ke pintu) di daerah perkotaan terbesar, dan kurang dari itu untuk kota yang relatif kecil. Kecepatan bus rata-rata tidak boleh turun hingga di bawah $10 \mathrm{~km} / \mathrm{jam}$ di daerah perkotaan yang padat dengan lalu lintas campuran (tanpa jalur bus prioritas) dan dalam kota bekepadatan sedang hingga rendah, kecepatan diharapkan mencapai sekitar 25 km/jam (Studi Pemodelan dan Data Transportasi Perkotaan dalam Meakin, 2011). Oleh karena itu, dalam perencanaan (planning) perlu dipikirkan akan waktu perjalanan atau rata-rata wajtu tempuh penumpang yang normal agar Suroboyo Bus dapat dimanfaatkan secara optimal oleh masyarakat Surabaya yang juga berguna mengurangi tingkat kemacetan di Surabaya.

\section{d. Transfer}

Kebutuhan untuk transfer antara trayek atau antara moda menambah waktu tunggu dan merupakan ketidaknyamanan bagi penumpang. Hal ini juga menambah biaya perjalanan penumpang sebagai penumpang mungkin harus dibayar untuk setiap mode atau layanan naik. Di kota besar banyak penumpang melakukan satu kali transfer tapi kurang dari 10\% penumpang melakukan transfer lebih dari satu kali. Oleh karena itu, hal ini menjadi penting untuk dievaluasi dan merencanakan perubahan struktur trayek dan untuk mengurangi jumlah transfer dengan menganalisis jumlah penumpang potensial dengan permintaan rute terbanyak juga area-area yang sering diakses oleh sebagian besar penumpang sehingga akan dapat 
mengurangi kebutuhan transfer penumpang dan akan memaksimalkan pemanfaatan Suroboyo Bus sebagai transportasi umum.

e. Biaya perjalanan

Sementara keterandalan secara konsisten dinilai sebagai kualitas yang paling penting dari sebuah jasa angkutan, biaya perjalanan dianggap sangat penting dalam pilihan moda oleh kelompok berpenghasilan rendah. Keterjangkauan dari trarif/ongkos bus tergantung pada tingkat pendapatan pengguna. Tarif yang terlalu tinggi menyebabkan banyak memilih untuk berjalan. Di negara berkembang tingkat biaya perjalanan bus yang wajar tidak melebihi 10 persen dari pendapatan rumah tangga. Meskipun dalam pembayaran Suroboyo Bus yang menggunakan botol bekas namun hal tersebut juga akan menjadi hambatan bagi penumpang yang tidak memiliki sampah botol plastik bekas sesuai jumlah yang ditentukan. Terlebih banyak warga yang belum memahami mekanisme pembayaran dengan sampah plastik tersebut (Jawa Pos, 2018). Dalam planning hal ini dapat dilakukan dengan adanya solusi pada tiket dari pengumpulan sampah milik orang lain, mengingat ada orang yang sering mengumpulkan banyak sampah plastik tetapi tidak butuh naik bus sering-sering sehingga dapat ditukarkan kepada calon penumpang yang membutuhkannya. Selain itu adanya penumpang yang tidak mau membawa sampah plastik kemana-mana akan diberikan solusi dengan adanya tempat penukaran atau bank sampah yang diberbanyak pada tempat-tempat tertentu. Menurut pakar atau ahli, kebijakan pembayaran tiket bus dengan sampah adalah solusi paling tepat, mengingat untuk naik Suroboyo Bus, pemkot tidak bisa menarik retribusi, sehingga kebijakan ini dinilai paling tepat dan efisien, karena dapat melibatkan warga untuk menjaga lingkungan kebersihan kota Surabaya.

Organizing dilakukan untuk menghimpun dan mengatur semua sumber-sumber yang diperlukan termasuk manusia, sehingga pekerjaan yang dikehendaki dapat dilaksanakan dengan baik (Hasibuan, 2011). Dalam pengorganisasian ini, upaya memanfaatkan berbagai pihak yang berkepentingan sangat penting sehingga perencanaan dapat berjalan dengan baik salah satunya melalui Public-Private Partnerships. Perkembangan teknologi dan tren di sektor swasta akan berdampak pada transportasi publik di masa depan. Public-Private Partnerships memberikan peran bagi pemerintah dan industri swasta dalam membangun infrastruktur transportasi, yang mengurangi beban satu pihak yang bertanggung jawab atas semua keuangan proyek. Jenis kemitraan ini biasanya memungkinkan proyek dibangun lebih cepat, tetapi sering kali memprivatisasi aset publik sebelumnya dan dapat membatalkan potensi imbal balik di masa mendatang atas aset tersebut. Public-Private Partnerships juga digunakan untuk proyekproyek yang lebih kecil seperti pembiayaan perkembangan penggunaan campuran di atau dekat halte transit.

Dalam hal ini, kemitraan multi aktor terdiri dari pemerintah yang berperan sebagai regulator, swasta mendukung kebijakan dengan membuat program untuk pembangunan masyarakat, sedangkan masyarakat berperan dalam bentuk pastisipasi. Saat ini perlu dibentuk UPT khusus mengelola pengoperasian Suroboyo Bus. Atau bisa dikontrak Manajemen ke pihak di luar Pemkot, mengingat saat ini pengelolaan Suroboyo Bus hanya ditangani oleh Dishub Kota Surabaya. Akan tetapi masih memiliki kendala pada rendahnya partisipasi masyarakat dalam pemanfaatan Suroboyo Bus sebagai transportasi umum. Selain itu dalam organizing juga penting melibatkan sektor swasta dalam hal pendanaan perbaikan aplikasi Gobis sebagai pemanfaatan teknologi informasi guna memberikan kemudahan kepada penumpang dalam penggunaan Suroboyo Bus. Melakukan kerjasama dengan sektor swasta 
untuk menyediakan beberapa layanan transportasi umum, menghasilkan efisiensi biaya dan kemampuan untuk lebih mudah memulai layanan baru. Teknologi dan inovasi yang dikembangkan di sektor swasta seperti penggunaan aplikasi Gobis menghadirkan peluang bagi badan publik untuk memberikan layanan dengan cara yang berbeda, meningkatkan pengalaman pengendara, dan menciptakan sistem transportasi yang lebih terintegrasi.

Integrasi dan kemitraan ini fokus pada penyediaan lebih banyak opsi mil terakhir kepada pelanggan dan akses yang lebih mudah ke opsi tersebut. Integrasi operator swasta juga membantu pelanggan menemukan alternatif transportasi umum, mengintegrasikan sistem pembayaran juga dapat dikembangkan kedepannya. Hal ini dilakukan karena inovasi teknologi telah lama diakui sebagai sumber utama pertumbuhan ekonomi dan peningkatan standar hidup. Pembuat kebijakan bertanggung jawab untuk menggunakan teknologi terbaru untuk menyediakan layanan ini sesuai dengan pertimbangan biaya-manfaat yang secara sederhana dapat meningkatkan kecepatan, keandalan dan keamanan perjalanan pengendara, sekaligus mengurangi biaya layanan jalan raya.

Actuating dilakukan dengan menggerakkan anggota-anggota kelompok, sehingga dapat berusaha untuk mencapai tujuan yang telah direncanakan bersama (Hasibuan, 2011). Dalam hal actuating terlihat masih kurangnya partisipasi masyarakat sehingga sangat penting dalam upaya menggerakan masyarakat agar aktif terlibat dalam penggunaan Suroboyo Bus sebagai transportasi umum sehari-hari. Hal ini dapat dilakukan dengan peningkatan intensitas sosialisasi baik di media cetak seperti koran, majalah maupun media elektronik seperti televisi dan radio juga media internet seperti melalui berbagai media sosial. Salah satu faktor kunci yang paling penting dalam mendukung keberhasilan reformasi angkutan umum adalah pengenalan sistem transportasi umum yang terintegrasi. Banyak negara telah menerapkan sistem semacam ini dalam konteks berbagai bentuk, situasi dan alasan, sehingga dapat meningkatkan kualitas layanan. Reformasi transportasi publik baik di London dan Seoul cenderung mengarah untuk memungkinkan lebih banyak koordinasi dan integrasi layanan yang disediakan oleh operator. Ini melibatkan berbagai bentuk kemitraan antara operator dan / atau otoritas (Harnis dan Mizokami, 2010). Sistem ini telah memberikan lebih banyak perencanaan dan pengendalian kompetensi kepada otoritas melalui organisasi publik yang diberdayakan yang mengoordinasikan sistem secara keseluruhan. Hal ini juga bertujuan untuk meningkatkan kualitas penyediaan layanan angkutan umum secara bersama-sama dengan upaya dalam menciptakan sistem transportasi yang terintegrasi secara efisien dan efektif. Dengan demikian, sistem semi publik bisa menjadi alternatif yang signifikan dalam melakukan reformasi transportasi bus umum (Harnis dan Mizokami, 2010).

Controlling dilakukan melalui adanya pemantauan dan penilaian rencana atas pencapaian tujuan yang telah ditetapkan guna menjamin bahwa tujuan dapat tercapai (Hasibuan, 2011). Pengawasan dilakukan agar sistem yang terintegrasi dapat berjalan secara optimal dan kontinyu. Perkembangan dan kemajuan dalam pelaksanaan transportasi tersebut perlu didukung dengan pelaksana dari kebijakan yang baik dan berkualitas pula dan perlu melibatkan berbagai kalangan bukan hanya dari instansi yang telah ditunjuk sebagai pelaksana kebijakan itu saja namun perlu adanya keterlibatan masyarakat diluar pelaksana kebijakan sebagai pengawas jalannya kebijakan tersebut sehingga ada yang selalu memantau apa yang telah dilaksanakan serta sejauh mana program tersebut dijalankan.

\section{KESIMPULAN}

Perlu adanya kebijakan yang mengatur pengelolaan Bus Surabaya anatar Pemerintah dan Swasta agar efektif penerepannya.Indikator kunci dari efektivitas jaringan bus adalah sejauh mana memenuhi kebutuhan perjalanan masyarakat. Perencanaan jaringan trayek secara 
sistematis meningkatkan efektivitas anggaran biaya secara keseluruhan. Peningkatan daya saing (dengan moda kendaraan pribadi) dilakukan dengan pemilihan jenis kendaraan angkutan yang tetap menjaga frekuensi layanan. Beberapa instansi pemerintah atau beberapa operator di kota-kota berkembang memiliki kemampuan untuk melakukan perencanaan jaringan secara sistematis. Sebuah proses perencanaan jaringan yang terus menerus dengan standar profesionalitas yang tinggi diperlukan kota-kota besar agar kebutuhan warga akan layanan angkutan umum dapat dipenuhi dengan baik.

Situasi di kota-kota maju sangat berbeda. Kebanyakan sistem bus kota di benua Eropa telah di subsidi sejak awal berdiri, dan juga di Amerika Serikat membutuhkan subsidi yang lebih besar karena kurangnya penumpang akibat beralih ke mobil pribadi. Di banyak kota, kebijakan mensubsidi angkutan umum telah lama dilakukan untuk memberikan alternatif untuk mobil pribadi dalam rangka memudahkan penduduk perkotaan, tujuan lingkungan dan kesetaraan mobilitas untuk semua warga negara. Hal ini lah yang menjadi acuan utama peningkatan sistem pembayaran dengan menggunakan sampah botol plastik guna mempermudah masyarakat sekaligus melibatkan mereka untuk menjaga lingkungan sekitar agar tetap bersih dari sampah-sampah.

\section{SARAN}

1. Diharapkan agar kedepannya dapat melakukan kerjasama dengan sektor swasta khususnya pada penambahan armada juga pengelolaan Suroboyo Bus kedepannya agar lebih terintegrasi juga dengan perbaikan sistem aplikasi Gobis yang berisikan jadwal dan rute pemberangkatan bus agar semakin dimanfaatkan oleh masyarakat secara optimal.

2. Perlu adanya sinergitas pengawasan yang komprehensif antara pihak-pihak terkait termasuk masyarakat dalam pengoptimalan Suroboyo Bus.

3. Diharapkan bagi peneliti selanjutnya agar bisa melihat aspek yang lebih komprehensif dan lebih luas terutama terkait dengan pengawasan dan evaluasi pelaksanaan kegiatan pengelolaan transportasi publik perkotaan.

\section{DAFTAR PUSTAKA}

Kurniawan, E. S., B. Pudjianto., \& Y.I. Wicaksono. (2009). Analisis Potensi Penerapan Kerjasama Pemerintah Swasta (KPS) Dalam Pengembangan Infrastruktur Transportasi Di Perkotaan (Studi Kasus Kota Semarang). Teknik - Vol. 30 No. 3

Nazir, M. (2014). Metode Penelitian. Bogor: Ghalia Indonesia.

Sugiyono. 2014. Metode Penelitian Kuantitatif, Kualitatif, dan Kombinasi (Mixed Methods). Bandung : Alfabeta

Susantono, B. \& Berawi, M.A. (2012) Perkembangan kebijakan pembiayaan infrastruktur transportasi berbasis kerja sama pemerintah Swasta di Indonesia”, Jurnal Transportasi, Vol. 12 No. 2, hal. 93-102

Undang-undang Nomor 32 Tahun 2009 tentang Perlindungan dan Pengelolaan Lingkungan Hidup

Puspita. 2018. "Dishub: Suroboyo Bus Bisa Turunkan Angka Kecelakaan", available on: https://www.republika.co.id/berita/nasional/daerah/18/04/08/p6v5x5428-dishubsuroboyo-bus-bisa-turunkan-angka-kecelakaan, diakses tanggal 7 Agustus 2018.

Kompasiana. 2018. "Suroboyo Bus Hadir untuk Mengurangi Sampah dan Kemacetan di Kota Surabaya", available on: https://www.kompasiana.com/mbakavy/5ad7f986ab12ae4502184c52/suroboyo-bus- 
hadir-untuk-mengurangi-sampah-dan-kemacetan-di-kota-surabaya, diakses tanggal 7 Agustus 2018

BBC News. 2017. "Antisipasi kemacetan, Singapura akan batasi jumlah mobil”, available on: https://www.bbc.com/indonesia/dunia-41733105, diakses tanggal 7 Agustus 2018

Sunaryo. 2015. "Rahasia Kota Seoul bebas macet dalam 11 tahun, Indonesia harus tiru", available on: https://www.merdeka.com/peristiwa/rahasia-kota-seoul-bebas-macetdalam-11-tahun-indonesia-harus-tiru.html, diakses tanggal 7 Agustus 2018

Jawa Pos. 2018. "Pengoperasian Suroboyo Bus Masih Gratis tapi Sepi Peminat", Available on: https://www.pressreader.com/indonesia/jawa-pos/20180410/282351155350656, diakses tanggal 7 Agustus 2018

Jawa Pos. 2014. "Kendaraan di Surabaya Tambah 17 Ribu Lebih Sebulan", available on: http://www2.jawapos.com/baca/artikel/9796/kendaraan-di-surabaya-tambah-17-ribulebih-sebulan, diakses tanggal 7 Agustus 2018

Jawa Pos. 2018. "Masa Tunggu di Halte 30-40 Menit", available on: https://www.pressreader.com/indonesia/jawa-pos/20180411/282402694960398, diakses tanggal 7 Agustus 2018

Berita Trans. 2015. "Kunci Sukes Singapura Menata Transportasi Kota Yang Bebas Macet”, available on: http://beritatrans.com/2015/05/26/kunci-sukes-singapura-menatatransportasi-kota-yang-bebas-macet/, diakses tanggal 7 Agustus 2018

Khafifah. 2015. "Begini Perbandingan MRT Singapura, Jepang dan Indonesia", available on: https://news.detik.com/berita/2933944/begini-perbandingan-mrt-singapura-jepang-danindonesia, diakses tanggal 7 Agustus 2018

Surya. 2018. "Dua Unit Suroboyo Bus Tak Beroperasi ternyata Ada Kerusakan di Bagian ini", Available on: http://surabaya.tribunnews.com/2018/04/23/dua-unit-suroboyo-bus-takberoperasi-ternyata-ada-kerusakan-di-bagian-ini, diakses tanggal 15 Agustus 2018

Salim, Abbas. 2012. Manajemen Transportasi. Jakarta: Raja Wali Press.

Adisasmita, Sakti Adji. 2011. Transportasi dan Pengembangan Wilayah. Yogyakarta: Graha Ilmu.

Miro. F. 2012. Perencanaan Transportasi. Jakarta: Erlangga.

Nasution, M Nur. 2008. Manajemen Transportasi, Edisi Ketiga. Bogor : Ghalia Indonesia.

Kamaluddin, Rustam. 2003. Ekonomi Transportasi; Karakteristik, Teori dan. Kebijakan. Jakarta: Ghalia Indonesia.

Setijowarno, D., dan Frazila, R.B. 2001. Pengantar Sistem Transportasi. Semarang: Universitas Katolik Soegijapranata.

Warpani, P. Suwardjoko. 2002. Pengelolaan Lalu Lintas dan Angkutan Jalan. Bandung: Penerbit ITB.

Meakin, Richard. 2011. Regulasi dan Perencanaan Bus, Modul 3c. Transportasi Berkelanjutan: Panduan Bagi Pembuat Kebijakan di Kota-kota Berkembang. Jerman: Federal Ministry for Economic Cooperation and Development 